\title{
ДОСЛІДЖЕННЯ ПОКАЗНИКІВ І ФОРМ АГРЕСІЇ УЧАСНИКІВ БОЙОВИХ ДІЙ НА СХОДІ УКРАЇНИ
}

УДК: 316.6

\section{Пустовий Олександр Миколайович}

Науковий кореспондент Інституту психологї імені Г. С. Костюка Начіональної академії педагогічних наук Украӥни, м. Кропивнищький (Украӥна)

Аннотация. У статті акцентовано увагу на різних формах агресї військовослужбовиів nід час проведення занять з бойової підготовки $і$ при виконанні бойових завдань. Обтрунтована актуальність визначення показників форм агресї та індексів агресивності $i$ ворожості військовослужбовиів за допомогою опитувальника А. Басса - А. Дарки. Показано переваги дослідження агресії військовослужбовців, для подальшого дотримання норм керування бойовою підготовкою підрозділу Проаналізовано результати емпіричного дослідження різних категорій військовослужбовців за фахом діяльності та порівняно групи військовослужбовців, які виконують однакові бойові завдання.

Ключевые слова: агресивність, ворожість, фізична агресія, непряма агресія, вербальна агресія.

Постановка проблеми та її зв'язок 3 важливими практичними завданнями. Планування бойової підготовки, управління в зоні проведення бойових дій та керування особовим складом під час виконання бойових завдань вимагає відповідальності за створення умов розвитку особистості військовослужбовців. Це пов'язане не лише 3 впливом бойової обстановки, а й з необхідністю напрацювання стійкості і підтримання певного рівня агресії як запоруки виконання бойового завдання. Розвиток проводиться в межах допустимих норм, підтримується на належному рівні та вимагає контролю за підвищенням рівня агресії.

Актуальною постає проблема вчасного визначення форм агресії та індексів агресивності і ворожості.

Метою статті $є$ розгляд форм агресії у військовослужбовців - учасників бойових дій на Сході України, визначити їх показники та дослідити індекси агресивності і ворожості.

Аналіз останніх досліджень і публікацій. Проблематика вивчення особистості військовослужбовців є завжди актуальною, що пов'язано 3 динамікою розвитку військової 
діяльності. Різні аспекти функціонування психіки військовослужбовця вивчались багатьма вітчизняними науковцями: М. Й. Варієм, C. Д. Максименком, В. В. Ягуповим, М. М. Дорошенком, В. Г. Коханом, О. Ф. Хміляром, О. П. Макаревичем, С. М. Потапчуком, В. В. Стасюком, О. О. Іллюком та ін.

При проведенні бойових дій на теритоpiї держави стають все актуальнішими проблеми комплектації військових частин особовим складом. Над цією проблемою в мирний час працювали О. М. Кокун, В. О. Баношенко, Н. І. Копаниця, Е. С. Литвиненко, В. Є. Солодовніков, Ю. А. Московчук, Д. Г. Любенок, О. П. Ковальчук, О. А. Матеюк, А. В. Сірий, В. І. Осьодло, Ю. А. Калагін. Особливої уваги потребує проблема не лише укомплектування, а й збереження військовослужбовців, що вже перебувають на військовій службі і знаходяться під негативним впливом війни.

Одним 3 найголовніших чинників війни $є$ агресія - поняття, яке в мирний час не привертало такої уваги. Найбільш відомими серед науковців, хто вивчав агресію $\epsilon$ : А. Басс, А. Дарки, А. Ассингер, Р. Берон, Д. Ричардсон, Е. Фромм, Л. Берковіц, Д. Саймон, Т. Лірі, К. Ізард, М. Зільман, К. Юнг, 3. Фрейд, К. Лоренц, Х. Кауфма. Д. Доллард, С. Фишбах, А. Бандура, Д. Кемпбелл, М. Шериф та ін.

Виклад основного матеріалу і результатів дослідження.
При потраплянні військовослужбовця до нового військового колективу, він завжди проходить три фази особистої згуртованості 3 іншими: адаптація, індивідуалізація, інтеграція. На перших двох фазах військовослужбовець може зазнавати значної деформації, а інколи може ігноруватися як такий, що не відповідає вимогам групи. Це може привести до таких змін, як негативізм, агресивність, підозрілість, неадекватна підвищена самооцінка. 3 часом він може зазнавати змін і в нього з'являються такі риси характеру, які є у більшості військовослужбовців даного колективу. Коли успішно проходить фазу інтеграції, в нього формується колективізм як риса особистості [7, c. 80-84].

Для ефективного проведення бойової підготовки і результативного виконання бойових завдань, під час підготовки військовослужбовці проходять різні заняття, в яких увага приділяється формуванню агресивної поведінки в межах норм. Агресивність як особистісна властивість людини є важливою ознакою, що характеризує військовослужбовця [4, c.c. 161, 106]. Крім того, агресивність може збільшуватись в результаті бойового стресу i фрустрації, як наслідок негативних емоцій [4, с. 191] і може перетворюватись в агресивну і конфліктну поведінку [4, с. 238]. Але для розгляду питання наслідків участі в бойових діях потрібно визначити що таке «агресія», «агресивність» і «ворожість» як складові агресії та показники їх виміру. 
Агресія - відхильна поведінка людини, яка заподіює моральний, фізичний і матеріальний збиток іншим людям або порушує їхній психічний комфорт (спричиняє негативне переживання, стан страху, пригніченості) [2, c. 222].

Але це поняття має більш широке значення. Дослідив і надав йому визначення А. Басс, згідно з яким агресія - це будь-яка поведінка, що містить загрозу або завдає шкоди іншим [1, с. 25]. Розширили це поняття інші науковці. Л. Берковіц вважав, щоб ті чи інші дії були кваліфіковані як агресія, вони повинні включати в себе намір скривдити чи образити, а не просто призводити до таких наслідків [1, с. 25]. В той же час, М. Зільман обмежує вживання терміну «агресія» спробою нанесення іншим тілесних чи фізичних ушкоджень [1, с.26]. Тому, агресія - це будь-яка форма поведінки, націлена на образу чи заподіяння шкоди іншій живій істоті, яка не бажає подібного звернення [1, с. 26]. Вона розглядається як зловмисна поведінка 3 емоційним збудженням або без нього. Агресія передбачає дії, за допомогою яких агресор навмисно заподіює шкоду своїй жертві. Її наміри - це особисті, приховані, недоступні прямому спостереженню задуми [1, с. 27], навіть якщо жертві, всупереч очікуванням, не було завдано шкоди. Тому, важливо визначати агресію не тільки як поведінку, що заподіює збиток або шкоду іншим, а й як будь-які дії, що мають на меті досягнення таких негативних наслідків [1, c. 28]. Слід зазначити, що нанесення тілесних ушкоджень реципієнту не є обов'язковим [1, c. 29], агресія стосується тільки живих істот, які намагаються уникнути агресивних дій на них $[1$, с. 30$]$.

Розрізняють два основних типи агресії: інструментальну (як засіб здобуття ресурсів, збиток не є самоціллю) і ворожу (як заподіяння страждань жертви) [1, с. 31].

Агресивність - це засіб, за допомогою якого індивідууми намагаються отримати свою долю ресурсів, в свою чергу, забезпечує успіх в природному відборі [1, с. 37]. Під агресивністю можна розуміти властивість особистості, яка характеризується наявністю деструктивних тенденцій, в основному в області суб'єктно-суб'єктних відносин [6, с. 240].

Ворожість - це неприязне ставлення до того, 3 ким людина перебуває в конфлікті. А. Басс розуміє ворожість як вузький за спрямованістю стан, який завжди має певний об'єкт. К. Ізард визначає ії як комплексну афективно-когнітивну рису або орієнтацію особистості. Почуття ворожості виявляється в емоціях злості (гніву), відрази й презирства із власними для них переживаннями і експресією, які можуть спричинитися до агресивної поведінки [2, с. 145].

3 огляду на те, що прояви агресії у людей нескінченні і різноманітні, А. Басс запропонував обмежити вивчення подібної поведінки концептуальними рамками. На його думку, агресивні дії можна описати на підставі трьох 
шкал: фізична - вербальна, активна - пасивна і пряма - непряма. Їх комбінація дає вісім можливих категорій, під які підпадає більшість агресивних дій [1, с. 29]. Саме ці вісім категорій і відповідають восьми станам агресії, які було запропоновано діагностувати розробленим методом А. Басса-А. Дарки (визначення фізичної агресії, непрямої агресії, роздратування, негативізму, образи, підозрілості, вербальної агресії, почуття провини). Даний метод має різні модифікації і назви, адаптовані різними мовами, але всі вони мають власну назву цих двох науковців, наприклад: визначення показників та форм агресії за методикою А. Басса та А. Дарки [5, с.с. 8285] - повний на 75 тверджень; самооцінка форм агресивної поведінки (модифікований варіант Басса - Дарки) [9, с.с .271-272] - скорочений на 40 тверджень. Обидва визначають вісім показників агресії, але в повному визначається індекс агресивності і індекс ворожості, скорочений використовується для дітей та підлітків. Раніше мав назву тесту ворожості, зараз відомий на весь світ, як опитувальник агресивності Басса-Дарки (англ. Buss - Durkee Hostility Inventory, скор. BDHI) призначений для виявлення рівня агресивності респондентів. Опитувальник складається з 75 тверджень.

Стаття присвячена дослідженню 3 використанням повної методики діагностування показників і форм агресії А. Басса та А. Дарки (адаптація О. Осницького), що складається 3 75 тверджень [3, с. 174-180]. Необхідно дета- льніше розглянути показники, які визначає дана методика.

Фізична агресія - використання фізичної сили проти іншої особи (бійка, штовханина).

Непряма - агресія, обхідним шляхом спрямована на іншу особу або ні на кого не спрямована (чутки, жарти).

Роздратування - готовність до прояву негативних почуттів при найменшому порушенні (запальність, грубість).

Негативізм - опозиційна манера в поведінці від пасивного опору до активної боротьби проти встановлених звичаїв i законів (направлена проти авторитету або керівництва).

Образа - заздрість і ненависть до оточуючих за дійсні і вигадані дії.

Підозрілість - в діапазоні від недовіри і обережності по відношенню до людей до переконання в тому, що інші люди планують i приносять шкоду.

Вербальна агресія - вираз негативних почуттів як через форму (сварка, крик, вереск), так і через зміст словесних відповідей (прокляття, погрози, лайка).

Почуття провини (аутоагресія) - висловлює можливе переконання суб'єкта в тому, що він є поганою людиною (діє шкідливо, злісно або безсовісно), а також відчуваються їм докори сумління [3, с. $179 ; 8$, с. 242].

Індекс ворожості включає в себе 5-ю і 6 -ю шкали, а індекс агресивності включає в се- 
бе шкали 1, 3, 7-ю. Нормою агресивності є величина іï індексу, що дорівнює $21 \pm 4$ (тобто

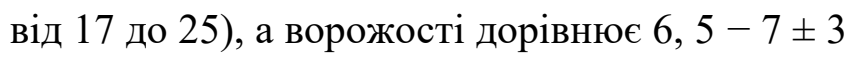
(тобто від 3,5 - 10). При цьому звертається увага на можливість досягнення певної величини, що показує ступінь прояву агресивності, максимальний індекс дорівнює 34, а максимальний індекс ворожості дорівнює 18 [6, с. 246].

У 2017 р. було проведено діагностування 100 військовослужбовців, які провели в зоні воєнного конфлікту одну ротацію, протягом 4 місяців. У дослідженні взяли участь кадрові військові, громадяни України віком від 19 до 44 років, чоловіки, які приймали участь в бойових діях. Метою було дослідити показники і форми агресії учасників бойових дій. Дослідження проведені для 3'ясування проявів агресії внаслідок фрустрації [1, с. 39] перед поверненням учасників бойових дій в місця постійної дислокації і визначення тих, хто потребує першочергового відновлення. Бойовий стрес, фрустрація та складні життєві ситуації супроводжуються гамою негативних емоцій і викликає у людини певні типові реакції: агресію спрямовану на себе (вербальну i невербальну), агресію, спрямовану на ілюзорного винуватця, агресію, спрямовану на подолання реальної причини перешкоди, переоцінку цілей і бажань, прояви невербальної агресії (рукоприкладство), прояви вербальної агресії (образа та приниження словами, лайка). [8, с. 8-39]. Також є необхідним перевірити показники агресії як такі, що з'являються тільки у відповідних соціальних умовах. I з'ясувати сприятливість умов групової взаємодії, які можуть накладати відбиток на кожного військовослужбовця. Правильне планування, керування і управління військовим колективом дають можливості запобігання агресії або взяття iï під контроль [1, с. 53].

У дослідженні взяло участь 100 військовослужбовців. В результаті аналізу емпіричних даних всього підрозділу ми отримали наступні результати, показані в таблиці 1 .

Таблиця 1

Загальні показники агресії досліджених військовослужбовців, $n=100$

\begin{tabular}{|l|c|c|c|}
\multicolumn{1}{|c|}{$\begin{array}{c}\text { Показники, } \\
\text { форми агресії }\end{array}$} & $\begin{array}{c}\text { Максимальне } \\
\text { значення (max) }\end{array}$ & $\begin{array}{c}\text { Середнє } \\
\text { значння (сер. } \\
\text { 3нач.) }\end{array}$ & $\begin{array}{c}\text { \% } \\
\text { від max }\end{array}$ \\
\hline Фізична агресія & 10 & 6,09 & 60,9 \\
\hline Непряма агресія & 9 & 3,7 & 41,11 \\
\hline Роздратування & 11 & 3,48 & 31,64 \\
\hline Негативізм & 5 & 1,34 & 26,8 \\
\hline Образа & 8 & 2,23 & 27,88 \\
\hline Підозрілість & 10 & 2,95 & 29,5 \\
\hline Вербальна агресія & 13 & 6,8 & 52,31 \\
\hline Почуття провини & 9 & 4,83 & 53,67 \\
\hline Індекс агресивності & 34 & 16,37 & 28,15 \\
\hline Індекс ворожості & 18 & 5,18 & 28,78 \\
\hline
\end{tabular}

Psychological Journal: Scientific Review of H. S. Kostyuk Institute of

Psychology, National Academy of Educational Sciences of Ukraine 
Якщо порівняти дані таблиці 13 нормами, можна стверджувати, що підрозділ має наближений до норми індекс агресивності (16,37 при нормі 17-25) та індекс ворожості в межах норми (16,37 при нормі 3,510). Це свідчить про те, що планування бойової підготовки, управління в зоні проведення бойових дій та керування під час виконання бойових завдань проводиться в межах допустимих норм і підтримується на належному рівні. Як наслідок, у військовослужбовців не відбувається підвищення рівня агресії і вони не перевищують зазначених норм.

3 отриманих результатів дослідження можна провести порівняльний аналіз та з'ясувати ті фахові напрямки, що виявляють найвищі та найвищі показники форм агресії та індекси агресивності і ворожості.

В результаті порівняння емпіричних даних військовослужбовців за фахом отримали наступні результати, показані в таблиці 2.

3 таблиці 2 видно, що військовослужбовці, які забезпечують діяльність підрозділу (забезпечення підрозділу), мають найнижчі показники за формами агресії, а саме фізичної агресії, непрямої агресії, роздратування, негативізму, вербальної агресії та індексу агресивності. Військовослужбовці, які виконують бойові завдання або операції (оперативні виконавці), мають найнижчі показники образи, підозрілості та індексу ворожості, але мають найвищій показник негативізму. Середні показники виявили військовослужбовці, що займаються плануванням і управлінням підрозділу (управління підрозділу), крім почуття провини, яке має найвищій показник серед всіх. Військовослужбовці, які керують групами військовослужбовців при бойовій підготовці та під час

Таблиия 2

Порівняння показників агресії військовослужбовців за фахом, n=100

\begin{tabular}{|l|c|c|c|c|c|c|c|c|}
\hline \multirow{2}{*}{$\begin{array}{c}\text { Показники, } \\
\text { форми агресії }\end{array}$} & \multicolumn{2}{|c|}{$\begin{array}{c}\text { Забезпечення } \\
\text { підрозділу, } \\
\text { n=13 }\end{array}$} & \multicolumn{2}{c|}{$\begin{array}{c}\text { Управління } \\
\text { підрозділу, } \\
\text { n=7 }\end{array}$} & \multicolumn{2}{c|}{$\begin{array}{c}\text { Оперативне } \\
\text { командування, } \\
\text { n=19 }\end{array}$} & \multicolumn{2}{c|}{$\begin{array}{c}\text { Оперативні } \\
\text { виконавці, } \\
\text { n=61 }\end{array}$} \\
\cline { 2 - 10 } & $\begin{array}{c}\text { сер. } \\
\text { знач. }\end{array}$ & $\begin{array}{c}\text { \% від } \\
\text { max }\end{array}$ & $\begin{array}{c}\text { сер. } \\
\text { знач. }\end{array}$ & $\begin{array}{c}\text { \% від } \\
\text { max }\end{array}$ & $\begin{array}{c}\text { сер. } \\
\text { знач. }\end{array}$ & \% від max & $\begin{array}{c}\text { сер. } \\
\text { 3нач. }\end{array}$ & $\begin{array}{c}\text { \% від } \\
\text { max }\end{array}$ \\
\hline Фізична агресія & 5,54 & 55,39 & 6,29 & 62,86 & 6,37 & 63,68 & 6,1 & 60,98 \\
\hline Непряма агресія & 3,15 & 35,04 & 3,57 & 39,68 & 4,42 & 49,12 & 3,61 & 40,07 \\
\hline Роздратування & 3,15 & 28,67 & 3,43 & 31,17 & 4 & 36,36 & 3,39 & 30,85 \\
\hline Негативізм & 1 & 20 & 1,29 & 25,71 & 1,32 & 26,32 & 1,43 & 28,53 \\
\hline Образа & 2,23 & 27,89 & 2,29 & 28,57 & 2,74 & 34,21 & 2,07 & 25,82 \\
\hline Підозрілість & 3,15 & 31,54 & 3,43 & 34,29 & 3,58 & 35,79 & 2,66 & 26,56 \\
\hline Вербальна агресія & 5,54 & 42,6 & 6,14 & 47,25 & 7,68 & 59,11 & 6,87 & 52,84 \\
\hline Почуття провини & 5,31 & 58,97 & 5,86 & 65,08 & 5 & 55,56 & 4,56 & 50,64 \\
\hline Індекс агресивності & 14,23 & 41,86 & 15,86 & 46,64 & 18,05 & 53,1 & 16,36 & 48,12 \\
\hline Індекс ворожості & 5,35 & 29,92 & 5,71 & 31,75 & 6,32 & 35,09 & 4,72 & 26,23 \\
\hline
\end{tabular}


безпосередньої участі в бойових діях (оперативне командування), не виявили жодного показника нижче всіх інших, а й показали найвищі форми агресії в 638 показників, а саме фізичної агресії, непрямої агресії, роздратування, образи, підозрілості, вербальної агресії (за показником негативізму поступились своїм підлеглим, а за почуттям провини своїм керівникам, які займаються управлінням підрозділу). Оперативне командування показало найвищі показники індексу агресивності і ворожості, вони знаходяться в межах визначеної норми.

В результаті порівняння емпіричних даних у військовослужбовців, які безпосередньо залучаються до виконання бойових завдань (оперативне командування та оперативні виконавці), нами отримано наступні результати, показані в таблиці 3.

Дані таблиці 3 засвідчують, що бойові групи, без урахування управління і забез- печення, мають найбільш наближені до норм індекси, в порівнянні з загальними даними таблиці 1 і не мають особливої відмінності одна від одної. Крім того, групи військовослужбовців співпадають за обома індексами, а саме група №1 має найнижчі індекси агресивності і ворожості, група № 2 - найвищі, група № 3 - середні.

Групи військовослужбовці, які виконують бойові завдання, а саме командири груп та військовослужбовці, які безпосередньо приймають участь в бойових діях (оперативне командування та оперативні виконавці) мають порівняно однакові показники форм агресії, які не мають значних відхилень між групами. Це свідчить про однакові заходи в проведенні занять з бойової підготовки, при управління підрозділом в цілому і керуванням групами військовослужбовців під час бойових завдань. Показники всіх трьох груп знаходяться в межах норми, що засвідчує

Таблиия 3

\section{Порівняння показників агресії військовослужбовців окремих груп, які безпосередньо виконують бойові завдання, $\mathrm{n}=80$}

\begin{tabular}{|c|c|c|c|c|c|c|c|c|}
\hline \multirow{2}{*}{$\begin{array}{c}\text { Показники, } \\
\text { форми агресії }\end{array}$} & \multicolumn{2}{|c|}{$\begin{array}{c}\text { Загальна } \\
\text { група, } \\
\text { n=80 }\end{array}$} & \multicolumn{2}{|c|}{$\begin{array}{c}\text { Група } \\
\text { №1, } \\
\mathrm{n}=28\end{array}$} & \multicolumn{2}{|c|}{$\begin{array}{c}\text { Група } \\
\text { №2, } \\
\mathrm{n}=27 \\
\end{array}$} & \multicolumn{2}{|c|}{$\begin{array}{c}\text { Група } \\
\text { №3, } \\
\mathrm{n}=25 \\
\end{array}$} \\
\hline & $\begin{array}{l}\text { cep. } \\
\text { знач. }\end{array}$ & $\begin{array}{c}\% \text { від } \\
\max \end{array}$ & $\begin{array}{l}\text { cep. } \\
\text { знач. }\end{array}$ & $\begin{array}{c}\% \text { від } \\
\max \end{array}$ & $\begin{array}{c}\text { cep. } \\
\text { знач. }\end{array}$ & \% від max & $\begin{array}{c}\text { cep. } \\
\text { знач. }\end{array}$ & $\begin{array}{c}\% \text { від } \\
\max \end{array}$ \\
\hline Фізична агресія & 6,16 & 61,63 & 5,71 & 57,14 & 6,07 & 60,74 & 6,1 & 60,98 \\
\hline Непряма агресія & 3,8 & 42,22 & 3,39 & 37,7 & 4,37 & 48,56 & 3,61 & 40,07 \\
\hline Роздратування & 3,54 & 32,16 & 3,25 & 29,55 & 3,85 & 35,02 & 3,39 & 30,85 \\
\hline Негативізм & 1,4 & 28 & 1,36 & 27,14 & 1,33 & 26,67 & 1,43 & 28,53 \\
\hline Образа & 2,23 & 27,81 & 1,82 & 22,77 & 2,26 & 28,24 & 2,07 & 25,82 \\
\hline Підозрілість & 2,88 & 28,75 & 2,71 & 27,14 & 3,3 & 32,96 & 2,66 & 26,56 \\
\hline Вербальна агресія & 7,06 & 54,33 & 7,29 & 56,04 & 6,93 & 53,28 & 6,87 & 52,84 \\
\hline Почуття провини & 4,66 & 51,81 & 4,96 & 55,16 & 4,55 & 50,62 & 4,56 & 50,64 \\
\hline Індекс агресивності & 16,76 & 49,3 & 16,25 & 47,79 & 16,85 & 49,56 & 16,36 & 48,12 \\
\hline Індекс ворожості & 5,1 & 28,33 & 4,534 & 25,2 & 5,56 & 30,86 & 4,72 & 26,23 \\
\hline
\end{tabular}


дотримання та підтримку на належному рівні всіх заходів в організації військової діяльності.

Висновки і перспективи подальших досліджень. У статті показано, що бойовий стрес підсилює прояви агресії військовослужбовців. Цей факт потребує уваги з боку управління підрозділом і командуванням під час виконання бойових завдань.

В дослідженні встановлено, що саме керівники груп не лише задають темп в підготовці та в керованості показників агресії, а й підтримують його у військовому колективі в межах норм. Військовослужбовці, які за фахом займаються забезпеченням діяльності підрозділу, мають найнижчі показники, управління підрозділу має посередні результати. Групи військовослужбовці, які саме виконують бойові завдання, мають майже однакові показники, в порівнянні одна з одною, що свідчить про однакові процеси проведення занять 3 бойової підготовки, управління підрозділом і керуванням під час бойових дій. Їх показники знаходяться в межах норми і засвідчують, що всі напрямки діяльності проводяться в межах допустимих норм і підтримується на належному рівні.

На наш погляд перспективою подальших досліджень буде проведення наукової роботи щодо емпіричної перевірки вже застосованих методів та методик на інших категоріях військовослужбовців.

\section{Перелік використаних джерел:}

1.Агрессия: Учебное пособие / Р. Бэрон, Д. Ричардсон. - СПб: Питер, 2001. - С. 352.

2. Варій М. Психологія: навчальний посібник /М.Варій - [2-ге вид. ]. - Київ: Центр учбової літератури, 2009. C. 288 .

3. Практическая психодиагностика. Методики и тесты: Учебное пособие /Д.Я. Райгородский. - Самара: БАХPAX-M, 2001. - С. 672.

4. Прикладная военная психология: Учебное пособие / А.Караяни, И.Сыромятников. - СПб.: Питер, 2006. C. 480 .

5. Психологу для роботи. Діагностичні методики: збірник /М.В. Левак, В.Ю. Петрище - [2-ге вид.]. - Ужгород: Видавництво Олександри Гаркуші, 2012. - С. 616.

6. Рогов Е. И. Настольная книга практического психолога: Учеб. пособие в 2 кн. /Е.И. Рогов - [2-е изд. ]. М.: ВЛАДОС, 1999. — С. 384.

7. Соииальная психология: Учебное пособие для студентов педагогических институтов /А.В. Петровский, В.В. Абраменкова, М.Е. Зеленова [и др.]; под ред. А.В. Петровского. - М.: Просвещение, 1987. - С. 224.

8. Теорія та практика збереження психічного здоров'я військовослужбовців: Монографія /Потапчук Є.М. Хмельницький, 2004. - С. 322.

9. Фетискин Н. П. Социально-психологическая диагностика развития личности и малых групп: учебное пособие /Н. П. Фетискин, В. В. Козлов, Г. М. Мануйлов. - М.: Институт психиатрии. 2002. - С. 490.

\section{References (Transliteration):}

1. Agressyja: Uchebnoe posobye / R. Bэron, D. Rychardson. - SPb: Pyter, 2001. - S. 352.

2. Varij M. Psyhologija: navchal'nyj posibnyk /M.Varij - [2 -ge vyd. ]. - Kyi'v: Centr uchbovoi' literatury, 2009. - S. 288.

3. Praktycheskaja psyhodyagnostyka. Metodyky y testu: 
Uchebnoe posobye /D.Ja. Rajgorodskyj. - Samara: BAHRAH-M, 2001. - S. 672.

4. Prykladnaja voennaja psyhologyja: Uchebnoe posobye / A.Karajany, Y.Suromjatnykov. — SPb.: Pyter, 2006. - S. 480 .

5. Psyhologu dlja roboty. Diagnostychni metodyky: zbirnyk /M.V. Levak, V.Ju. Petryshhe - [2-ge vyd.]. Uzhgorod: Vydavnyctvo Oleksandry Garkushi, 2012. - S. 616.

6. Rogov E. Y. Nastol'naja knyga praktycheskogo psyhologa: Ucheb. posobye v 2 kn. /E.Y. Rogov - [2-e yzd. ]. - M.: VLADOS, 1999. - S. 384.

7. Socyal'naja psyhologyja: Uchebnoe posobye dlja studentov pedagogycheskyh ynstytutov /A.V. Petrovskyj, V.V. Abramenkova, M.E. Zelenova [y dr.]; pod red. A.V. Petrovskogo. - M.: Prosveshhenye, 1987. — S. 224.

8. Teorija ta praktyka zberezhennja psyhichnogo zdorov'ja vijs'kovosluzhbovciv: Monografija /Potapchuk Je.M. - Hmel'nyc'kyj, 2004. - S. 322.

9. Fetyskyn N. P. Socyal'no-psyhologycheskaja dyagnostyka razvytyja lychnosty y maluh grupp: uchebnoe posobye $/ \mathrm{N}$. P. Fetyskyn, V. V. Kozlov, G. M. Manujlov. - M.: Ynstytut psyhyatryy. 2002. - S. 490.

\section{Pustovy Olexander}

Scientific correspondent, H. S. Kostiyk Institute of Psychology of The National Academy of Educational Sciences of Ukraine, Kropyvnytskyi (Ukraine)

\section{STUDY OF INDICATORS AND FORMS OF AGGRESSION OF PARTICIPANTS OF MILITARY ACTION IN THE EASTERN UKRAINE}

\begin{abstract}
When performing a combat task for a servant, special features of a person are important. These features are related to personality related to aggression. They are necessary for the
\end{abstract}

preservation of one's own life, the destruction of the enemy and its objects. These features impose an imprint on the interaction of military personnel in the military team. They are important in the system of socio-psychological factors of the group interaction of servicemen. In group interaction, some features of the personality of a serviceman can appear as aggressive. This can happen in a conflict and have aggressive behavior altogether. These factors have a separate aggressive effect. They manifest themselves in various forms and types of aggression. The question arises as to the definition of indicators of aggression, and the indices of aggression and hostility.

Changing aggression rates is a result of group interaction. The change may be larger or smaller. Teamwork of military personnel imprints on the identity of each individual soldier. With proper planning, unit management and personnel management, aggression rates remain within normal limits.

During combat stress and frustration, the level of aggression is changing. Aggression is the result of frustration. Aggressive actions are divided into three scales: physical and verbal, active and passive, direct and indirect. Aggression is a combination of three scale scores. It can be manifested in the form of physical aggression, indirect aggression, irritation, negativism, insults, suspicion, verbal aggression, feelings of guilt.

The purpose of the study is to determine the rates of aggression of combatants. The study involved participants in combat operations in 
eastern Ukraine. The study was conducted by the Burs-Durkee Hostility Inventory (BDHI). Indices of aggressiveness and hostility are determined.

Keywords: aggressiveness, hostility, physical aggression, indirect aggression, verbal aggression.

\section{Пустовой Александр Николаевич}

Научный корреспондент Института психологии имени Г. С. Костюка Национальной академии педагогических наук Украины, г. Кропивницкий (Украина)

\section{ИССЛЕДОВАНИЕ ПОКАЗАТЕЛЕЙ И ФОРМ АГРЕССИИ УЧАСТНИКОВ БОЕВЫХ ДЕЙСТВИЙ}

Анотация. В статье акцентировано внимание на различных формах агрессии военнослужащих при проведении занятий по боевой подготовке и при выполнении боевых задач. Обоснована актуальность определения показателей форм агрессии и индексов агрессивности и враждебности военнослужащих с помощью опросника А. Басса - А. Дарки. Показаны преимущества исследования агрессии военнослужащих, для дальнейшего соблюдения норм управления боевой подготовкой подразделения. Проанализированы результаты эмпирического исследования различных категорий военнослужащих по специализации деятельности и проведено сравнение групп военнослужащих, выполняющих одинаковые боевые задачи.

Ключевые слова: агрессивность, враждебность, физическая агрессия, косвенная агрессия, вербальная агрессия.

Дата отримання статті: 17.12 .2017

Дата рекомендації до друку: 20.12.2017 